\title{
The Scientific Analysis of Hungarian Public Administration. New Trends and Methods.
}

\author{
Ádám Rixer \\ Károli Gáspár University of the Reformed Church in Hungary \\ Law Faculty, Budapest, Hungary \\ rixer.adam@kre.hu
}

\begin{abstract}
The purpose of this paper is to introduce those scientific methods and new paradigms that are to overcome the one-sided jurisprudential methods of analysis of public administration. On the one hand, as it has been obvious for a long time, a sort of inter- or multidisciplinary method is needed for a strong scientific and material framework which allows further conclusions. And on the other hand, beyond multi- and interdisciplinarity, it is unavoidable to reestablish the philosophic synthesis between the legal norms regulating public administration and the facts of the real operation. Probably this direction will/ may be the basis and the realiser of the change of paradigm (also) in Hungarian sciences of public administration. In general it may be stated that due to the crises social sciences more and more shall start examining the real meaning of things, the broader examination frameworks of the analysed phenomena, instead of descriptive questions analysing the ways of operation. In the era of crises, when everyday experiences falsify our expectations, legal and political science become more radical: it shall examine and revise the validity of its preassumptions - which it had considered firm before.
\end{abstract}

Keywords: administrative sciences in Hungary, multi- and interdisciplinarity, philosophic synthesis, natural law approach

JEL: K 190

\section{Introduction}

Hungarian public administration and science of public administration traditionally - are very much of legal character. This is not changed by the fact that the most acknowledged researchers of the science of public administration (earlier Zoltán Magyary, in the near past Lajos Lőrincz) often expressed their concerns about the one-sided legal analysis of public administration. Nevertheless, the analysis of public administration primarily with jurisprudential methods and from a legal approach is comfortable, because "(...) the questions of public administration may be homogenised legally, and its mechanisms have been consciously based on law since the beginning of the 19th century" (Tamás, 2011, p. 67-68), therefore this is 
determinative also in practice. According to the data of a survey published not long ago, the civil servants questioned - in their own opinion - spend exactly two-thirds of their office hours on legal activities, and this rate is slightly higher in case of jurists working in public administration (68\%) (Gajduschek, 2011, p. 395).

According to the presently prevailing majority opinion, the narrowest examination possibility of any field of public administration is the analysis of the internal principles of administrative law. It provides for a wider analysis, and thus for a kind of "legal internal multidisciplinarity" if we compare the institutions of public administration with similar institutions of other fields of law: e.g. comparing administrative responsibility, as a sub-type of the system of legal responsibility, with the elements composing the system of responsibility in other fields of law (Nagy, 2011, p. 200).

The necessity of "internal legal multidisciplinarity" is supported also by some specific features of relationships regulated by administrative law: we shall pay attention to the fact that the number and significance of those complex legal relationships which are established in the "overlap", at the borders of administrative law and civil law is rising. ${ }^{1}$ Thus for example in relation with public services (permitting) decisions delivered based on administrative rules originating from acts or decrees, and the civil law contracts realising these decisions compose a unified, complex (mixed) legal relationship in which the various elements materially overlap each other. ${ }^{2}$ The decisions and contracts assume each other, and therefore their realisation is shared too. Grasping these complex legal relationships is a difficult issue, both in legislation and in law enforcement, especially that "the dogma of such complex (mixed) legal relationships is less worked out" ${ }^{3}$, even though - as has been mentioned - this is not a new phenomenon. ${ }^{4}$

Experiences the significance of which is magnified by the crisis show that the interests of the national economy and other aspects more and more require the limitation of contractual freedom from the interests of the public. "In developed modern legal systems such areas of limitation are especially the

1 Károly Szladits has already written about this phenomenon in 1941 that "(...) there are amphibian, mixed legal situations, which are of public law features in one part and of civil law features in the other. (...) The direction of legal development turns towards the combination and commutability of public law and civil law institutions: new reorganisations are going on in front of our eyes, especially in the area of the so-called economic law (...), which unite public law and civil law elements in a new synthesis." (Szladits, 1941, p. 20) According to Article 198 paragraph (3) of Act IV of 1959 on the Civil Code (Ptk.) "An obligation or an entitlement to services may be constituted, on the basis of legal regulation or official order, without the conclusion of a contract if so ordered by the legal regulation or competent authority, and if the obligor, the obligee, and the service are accurately specified. In such case, the provisions on contracts shall be duly applied, unless otherwise provided by legal regulation or official order."

2 Reasoning of the 3062/2012. (VII. 26.) ABH Constitutional Court Decision.

3 Ibid.

4 About the features of relationships in the "no man's land" between administrative law and civil law see Harmathy (1983, p. 84). 
law of the limitation of competition, cartel law, abuse of economic power, supervision of organisational associations, price regulation, standard contracts, protection of the environment, protection of consumers, etc. In these fields of regulation, the contractual freedom of the parties is often doubted, as well as the determination of the contracts' contents by the parties, and moreover, the unaltered nature of the content of contracts." ${ }^{5}$

Since the second part of the $19^{\text {th }}$ century, university education and scientific research have considered legal interpretation determinative. Differences may be observed only in some minor issues, such as in addition to "descriptive" explanations, the number of works describing and analysing the public law/constitutional law frameworks has been increasing lately. Moreover, the examination of the legal system (and of institutions showing a close relationship with public administration) is more and more simplified to exclusively constitution-based evaluation with aspects of constitutionality. ${ }^{6}$ However, in the case of this approach - which has been strengthened by the approval of the Fundamental Law of Hungary on 25 April 2011 and its entering into force on 1 January 2012 - it is important that "The examination of [the] constitution, as norm category, considering its establishment, modification (amendment), subject, effect and unique characteristics requires the consideration of a complex system of aspects." (Csink \& Fröhlich, 2012, p. 13) One reason for this is that "constitution making is an act of legal and political nature at the same time. The decision whether a new constitution is needed is made outside of the legal system. It is not a concern of law either which should be the main directions of a new constitution (e.g. form of government, mechanisms for the protection of fundamental rights, etc.). These decisions shall be made via politics." (Csink \& Fröhlich, 2012, p. 13) A constitution always contains at least two types of norms: ones related to positive law, and one containing political norms. Constitutional law analysis is always needed, but it can never be exhaustive if it excludes the description of the nature of political norms (Szigeti, 2011, p. 53). In a broader approach: the material problem of constitution making cannot be managed exclusively from a legal or jurisprudential point of view; the catalogue of questions and the pool of answers which provide for the completion of the task may be put together only upon a summary of the aspects and opinions of several professional fields.

\section{The Significance of Inter- and Multidisciplinarity in Administrative Research}

In addition to the above mentioned factors our presumption is that in connection with the direct subject of this work - public administration -

5 Reasoning of the 32/1991. (VI. 6.) ABH Constitutional Court Decision.

6 Examining the issue from a different approach, we may observe that it seems that the analysis of certain fields of social phenomena (analysed also in this work) is "reserved" exclusively to the sciences of constitutional law and legal sociology. 
a sort of inter- or multidisciplinary method is needed for an examination which allows for drawing credible further conclusions and founding new analyses; thus in the examined subject - in addition to the methods and results of the traditionally strongest administrative jurisprudence - a strong scientific and material framework should be established from the scientific methods of other social sciences, ${ }^{7}$ such as political sciences, organisational sciences (organisation-management sciences), public policy science, the narrowly interpreted science of public administration (theory of public administration and economics), broadly interpreted management sciences, statistics, sociology, social psychology or Christian social ethics or ethics of economics (!), moreover, certain natural sciences, in which, or compared to which the narrowly interpreted jurisprudential reasoning and textual examinations may receive their real place and value.

International literature refers to the fact that in the attempts at description made by different public administrations, public policy and institutioncentred approaches were in an almost monopolist situation for a long time, also at international level (Van der Hoek, 2005). We shall direct our attention to the fact that the rather traditional methods of the science of public administration, administrative-sociology and science of economy are nowadays supplemented by approaches of network theory which аге more suitable for analysing the globalised world (Nagy, 2011, p. 207-209). In order to see the full picture, it must be added that the examination of administrative phenomena is not only affected by the proper scientific field and method; ideological relations are also equally important, which may be considered as separate directions with scientific appearance, and may be separated from each other: "During the scientific analysis of Hungarian public administration traditionally we may distinguish between at least three approaches: the classic method of Weber, the public policy approach stressing social effects, and that of public management." (Gajduschek, 2011, p. 391)

For the establishment of dialogue between law and other forms of knowledge, a strongly inter-disciplinary starting point is needed (Sherwin, 2009). Today this means more than the application of the methods of sociology or discussion-analysis for a better understanding and overview of legal processes. The need to turn towards new (scientific) fields has been formulated, new fields which have not or have not really been in connection

7 About the possible use of natural scientific approaches and methods see e.g. Nagy (2010). 
with the science of law or economy before (science of literature ${ }^{8}$, cultural anthropology (Freeman \& Napier, 2009, p. 47), or psychology and cognitive nerve sciences, etc.). Moreover, nowadays the relationship of these cannot be limited to "mutual introduction" at the level of generalities, but rather the establishment of previously formed inter-disciplinary procedures and related coherent and systematic methods is necessary, which are able to provide a firm framework for material comparative analyses/research, and at the same time are committed to flexibility and openness (Rothchild, 2009, p. 476).

Naturally, in the examination of administrative (state) phenomena this need - observable in the above-mentioned multidisciplinary approach - does not appear only in the narrowly interpreted science of public administration and administrative legal science. Gyula Gulyás - approaching the subject from his own field, the science of public policy-writes the following:"Multidisciplinarity requires a break-up with the one-sided political analysis of institutions and structures [thus administrative institutions and structure]: these examinations shall be supplemented with the theoretical and methodological possibilities offered by sociology, economics and legal sciences." (Gulyás, 2002, p. 69)

This complex approach - regarding all administrative phenomena - is justified by the fact that the difference between change processes emerging in law and real social changes has traditionally faded away: "[T] he need to get used to the new, and the significance of the management of society mostly by law shows shifts even in cases when in reality nothing happens." (Sajó, 1988, p. 7)

Due to these features (characteristics) during the examination the method of model making should be used, if public administration may be interpreted as an adaptive complex method - in which the separate examination of certain

8 Law and literature is becoming a new discipline also in Hungary. (For instance Szilágyi, 2010; Nagy, 2011; Kiss, Kiss \& Tóth (Eds), 2010) It aims at revealing the literary context of legal phenomena. According to the simplest - and perhaps most applied - scheme there are two specific approaches in the research field: the first one examines how law appears in literature (law in literature), while the other one treats law as a special field of literature (law as literature).

In addition to the fact the law in literature approach is closely related to the criticism of law the picture of law in literature may be also used as source of legal history and the history of ideas. Moreover literary works - especially the modern novel - may also serve as valuable sources for legal sociological research. In this latter discipline - based on the "living law" concept of Ehrlich - the first works mentioning the possibility of this approach in the analysis of documents appeared in the 1970s. Such analyses may provide valuable help for example in reviewing the ideas of society about jurists. According to the law as literature concept literature and law may be interpreted as different directions or methods of the continuum of linguistic actions, but both are actions expressing or establishing the identity of the individual and of society at the same time. The basic function of law is to hold society together, and therefore its essence is constitutive rhetoric - namely the "re-telling" of the stories of society members which facilitates the return of the individual to the community or the establishment of its (new) role, as a closure of the conflict handled by law.

Based on the above-mentioned, the appearance of the structures, operation and staff of the strictly legal public administration in old or modern literature may contribute to better scientific understanding (researchability) of the real movements, rules, possible new directions or repeated specialities of public administration. These ideas are still theoretical, and substantial research regarding this context has not been performed in Hungary yet. 
elements significantly decreases the value of possible explanations. In this model, the relationship of the state, moreover, of the broadly interpreted administrative institutions to society, other authorities, market and international integrations, etc. - due to the conflicts of the above-mentioned pretence created by law and reality - shall be examined from all possible aspects also with the approach whether the administrative reforms have touched upon the merits of the system of relations, and if yes, how and at what degree (Gellén, 2012, p. 14).

In order to present the full picture it must be mentioned that methods and procedures pointing in the direction of interdisciplinarity require the utmost care, because the clarity of terminology is extremely important in this aspect. For example, the notion of governmental capacity - in its broadest meaning refers to the ability of the state through which - in hope of realising its public policy goals - it is able to overcome certain difficult, hampering circumstances (Bevir, 2009, p. 41). Part of our uncertainties about notions - with legal, economic, etc. contents - originates from the fact that it is very difficult to find material, useful indicators which meet the standards of comparison, especially that these are often very complex 'sets of aspects' composed of several elements. One of them - for example - is the approach from the side of trust capacity (Boda \& Medve-Bálint, 2012, p. 27), which - beyond the traditional measurements of trust towards institutions - is not afraid of the complex examination of mutualities based on trust, among other things (Meleg, 2012).

\section{Beyond Multi- and Interdisciplinarity: New Approach of Social Sciences}

As in other fields, modernity has resulted in the introduction of new explaining principles in political philosophy. For a long time majority of authors discussing good governance and the order of social coexistence explained the 'human phenomena' based on the presumptions of the ontology and epistemology of the Cartesian-Newton ethos', which was dominant for a long time in modern natural sciences, and they considered any other approach irrational: the individual was considered the natural starting point and atomic element of social examinations (Lányi, 2012, p. 105). Either this way or the other, they derived the right to existence of political institutions from the authorisation received from individuals and/or from natural efforts attributed to individuals, and traditional heritage and the 'blind' forces of nature were only considered obstacles to be overcome in order to allow for the undisturbed establishment of the individual. The unbounding of the personality, emancipation became the main political (and administrative) goal, the main tool of which (in mainstream approaches) is clear, rational power. 
Today's canon requires the researchers of society to distinguish clearly between statements of fact and statements containing value judgements. The 'scientific majority' tends to accept as scientifically valuable and thus realistic only the former ones (Lányi, 2012, p. 106). However, the global spread of rational institutions led to great political changes by the end of the 20th century, in so far as the [complex] operation of "knowledge power" embodied in networks, technologies and formalised relations (e.g. law, market, IT) has become more and more uncontrollable and pressing, including the fact that attempts at description with traditional methods have become impossible.

As Marianna Nagy puts it, in regards to the question of "why law is not working", we have not received sufficient answer yet (Nagy, 2011, p. 207); the traditional, "usual" methods of the broadly interpreted economic science and the related - typically social scientific - fields do not give answers. It is unavoidable to re-establish the philosophic synthesis between legal norm regulating public administration and the facts of the real operation. Probably this direction will/may be the basis and realiser of the change of paradigm (also) in Hungarian sciences (of public administration).

In general it may be stated that due to the crises social sciences more and more shall start examining the real meaning of things, the broader examination frameworks of the analysed phenomena, instead of descriptive questions analysing the ways of operation. In the era of crises, when everyday experiences falsify our expectations, legal and political science become more radical: it shall examine and revise the validity of its preassumptions - which it had considered firm before. "Therefore philosophy has become valid again, as it is more and more difficult to exclude questions from political scientific (and economic scientific) discussion which is averted from philosophic questioning, appearing with the requirement of descriptive science which are not related to the method of operation, but to its meaning (the framework of meaning)." (Lányi, 2012, p. 107) The attention of jurisprudence is turning - among others - to the issue of how it is possible that moral principles are more and more present in the world of law, also in fields where the need for these is a long repeated fact, but the practical incorporation has not happened or has just partly happened (see. e.g. the issue of moral responsibility of the majority society towards the Roma minority in the legal instruments of Hungary). A definite sign of the expansion of the horizon of jurisprudence - interpreted in the broadest sense - is that the warriors of "traditional" legal positivism keep establishing their own systems of criteria, through which this incorporation may provenly take place in all possible fields (Kramer, 2008, p. 17).

\subsection{Strengthening of the Natural Law Approach}

For modern people the functional differentiation of society is an experience; the more and more obvious autonomy of politics, law, economy, science and the part systems of religion, which have meant significant challenge for social sciences when they should have described this acentric - centreless - 
world (Cs. Kiss, 1994, p. 7-8). The feature of modern and 'post-modern' social science concepts conceived in the era without a central guiding principle is that they do not (or not much) consider the philosophic-moral nature of man, and they do not touch upon the principles of proper social coexistence and order related to society integrative forces, and this way they also give up the theoretical founding of a feasible social order (Frivaldszky, 2007, p. 382).

In early cultures, law and religion typically formed a unified knowledge complex which identified itself eventually as a gift of God, as power organising knowledge, (sometimes) with ambiguous origin, bequeathed orally across the generations (Juhász, 2011, p. 8). One of the main effects made on the present state of modern law and jurisprudence originated from - earlier - the break up with the exclusivity of divine natural law: the transcendent (moral) verification of the validity of positive law made by man profanised in form of rational natural law (Cs. Kiss, 1994, p. 8). Even though the need to verify the validity of positive law with transcendent, so-called meta-juristic (moral) principles has not vanished yet, the verification problem itself shifted into the dimension of the history of the non-created world. Pál Kecskés wrote: "As the conservativism of the historical-legal school established in the concept of Romanticism considered customs which appeared in the historical spirit the origin of positive law, with the urging of the historical method it significantly facilitated the creation of legal positivism" (Kecskés, 2002, p. 219-220), which, by rejecting metaphysics - thus the existence and role of God - considered only concrete, positive law as the only existing and valid law (therewith that in its opinion the only possible background reason of the created rules must be found in historical circumstances). In this approach, the notion of law is limited to the material (positive) law, the only origin and therefore interрreter of which is the state, or the will of the state.

Natural law itself has always had a double meaning: the approach interpreting nature in a metaphysical - religious - way has always been contradicted with the new (16-18 ${ }^{\text {th }}$ century), "enlightened, rationalist - or in other words layman-approach - interpretation of natural law", which by providing specific, empirical meaning to nature attaches the notion of natural law to an empirical feature of human nature (typically to its instinct, or any easily recognisable need).

With the advancing of the positivism of the law, the separation/division of ethics and law (morality and legality) from the strengthening of legal positivism, pushing the natural law approach to the background, there has been the following alternative solution for the question of the 'origin and nature' of legal validity: the positive law becomes valid either through a decision delivered in a target rationalised (legal!) procedure, and it does not need any transcendent justification beyond law, or there is a need for external justification, reliance on metajuristic (moral) principles. At this time it must be stated that nowadays we may witness the slow strengthening of the natural law approaches, interpreted in the broadest sense. Regarding legal positivism, 
which can still be considered the ruling approach, it is a realistic assumption that 'law as momentum related to the system of norms and values requires the certification of its validity, and the changing world of positive experience cannot serve as sufficient justification; it could remain in the shadow only till the wise spirit was tied down by one-sided natural scientific knowledge' (Kecskés, 2002, p. 220).

Adam Rixer Ph.D. is Head of Department of Public Administration for the Law Faculty of Károli Gáspár University (Budapest) of the Reformed Church in Hungary. His main fields of research are legal aspects of the relationship between governmental bodies and civil/non-profit entities, especially churches, and also contemporary features of the Hungarian public administration. He has written two books in English [Religion and Law, Budapest, Patrocinium, 2010; Features of the Hungarian Legal System after 2010, Budapest, Patrocinium, 2012]. He is member of the Subcommittee of Administrative Sciences of the Hungarian Academy of Sciences. 


\section{References}

Bevir, M. (2009). Key concepts in governance. Delhi: SAGE.

Boda, Zs. \& Medve-Bálint, G. (2012). Intézményi bizalom a régi és az új demokráciákban [Institutional trust in old and new democracies]. 2 Politikatudományi Szemle, 21, 16-40.

Cs. Kiss, L. (1994). Bevezetés [Introduction]. In: Cs. Kiss, L., \& Karácsony, A. (Eds.) A társadalom és a jog autopoietikus felépítése [Autopoietical structure of society and law] (5-17). Budapest: ELTE.Cs. Kiss, L. (1994). Bevezetés [Introduction]. In L. Cs. Kiss, \& A. Karácsony (Eds.), A társadalom és a jog autopoietikus felépitése [Autopoietical structure of society and law] (p. 5-17). Budapest: ELTE.

Csink, L. \& Fröhlich, J. (2012). Egy alkotmány margójára. Alkotmányelméleti és értelmezési kérdések az Alaptörvényröl [On the margin of a constitution: Constitutional scientific and interpretation issues regarding the Fundamental Law]. Budapest: Gondolat Kiadó.

Freeman, M. \& Napier, D. (2009). Law and Anthropology. Current Legal Issues, 12, 40-64.

Frivaldszky, J. (2007). Klasszikus természetjog és jogfilozófia [Classic natural law and legal philosophy]. Budapest: Szent István Társulat.

Gajduschek, Gy. (2011). A közigazgatás értelmezése Magyarországon [Interpretation of public administration in Hungary]. In P. Takács (Ed.), Ratio Legis - Ratio luris: Ünnepi tanulmányok Tamás András tiszteletére 70. születésnapja alkalmából [Ratio Legis - Ratio luris Essays for the 70th birthday of András Tamás] (p. 390-396). Budapest: Szent István Társulat.

Gellén, M. (2012). A közigazgatási reformok az államszerep változásainak tükrében [Administrative reform in light of the changes of the role of state]. Phd. Győr: SZIE ÁJ DI.

Gulyás, Gy. (2002). A közpolitika paradoxonai [Paradoxons of public policy]. Phd. Budapest: ELTE.

Szilágyi, H. I. (2010). Jog és irodalom [Law and literature]. Iustum Aequum Salutare, 6, 3-19.

Harmathy, A. (1983). Szerződés, közigazgatás, gazdaságirányitás [Contract, public administration, economic control]. Budapest: Akadémiai Kiadó.

Juhász, Z. (2011). De iure non scripto, avagy a korai jogfogalom duplexivitása [De iure non scripto, i.e. the duplexivity of the early notion of law]. 1 De lurisprudentia et lure Publico, 5, 1-8.

Kecskés, P. (2002). Természetjog [Natural law]. In M. Szabó (Ed.), Natura luris (p. 216-234). Miskolc: Bíbor Kiadó.

Kiss, A., Kiss, H., \& Tóth J., Z. (Eds.). (2010). Csíny vagy bün? [Prank or sin?]. Budapest: COMPLEX Kiadó.

Kramer, M. H. (2008). Where Law and Morality Meet. Cambridge: Cambridge University Press.

Lányi, A. (2012). Az ökológia mint politikai filozófia [Ecology as political philospohy]. 1 Politikatudományi Szemle, 21, 103-118.

Meleg, Cs. (2012). A bizalom hálójában - társadalmi nézőpontok [In the net of trust - approaches of society]. JURA, 14, 72-75. 
Nagy, M. (2011). A közigazgatási felelősség - mi van a jogon túl? [Administrative responsibility - what is beyond law?]. In M. Fazekas (Ed.), A közigazgatás tudományos vizsgálata egykor és ma: 80 éve jött létre a budapesti jogi karon a Magyar Közigazgatástudományi Intézet [The scientific analysis of public administration in the past and today: The Institute of Hungarian Public Administration was established 80 years ago at the law faculty of Budapest] (p. 198-212). Budapest: Gondolat Kiadó.

Nagy, M. (2010). Interdiszciplináris mozaikok a közigazgatási jogi felelösség dogmatikájához [Inter-discpilinary mosaics to the dogmatics of administrative law responsibility]. Budapest: ELTE - Eötvös Kiadó.

Nagy, T. (2011). Jog, irodalom, intertextualitás [Law, literature, intertextuality]. In P. Takács (Ed.), Ratio Legis - Ratio luris. Ünnepi tanulmányok Tamás András tiszteletére 70. születésnapja alkalmából [Ratio Legis - Ratio luris. Anniversary essays for the 70th birthday of András Tamás] (p. 38-47). Budapest: Szent István Társulat.

Rothchild, J. (2009). Law, Religion, and Culture: The Function of System in Niklas Luhmann and Kathryn Tanner (2008-2009). Journal of Law and Religion, 24, 465-491.

Sajó, A. (1988). Társadalmi-jogi változás [Social-legal change]. Budapest: Akadémiai Kiadó.

Sherwin, R. (2009). Intersections of Law and Culture. A cross-disciplinary conference hosted by the Department of Comparative Literary and Cultural Studies, Franklin College Switzerland, Lugano, October 2, 2009.

Szigeti, P. (2011). Társadalomkutatás - mi végre? Politikatudomány - Alkotmányjog - Világrendszerelmélet. [Research of society - for what? Political science Constitutional law - Global system theory]. Győr: Széchenyi István Egyetem (Publicationes Jaurinenses op. 9).

Szladits, K. (1941). Magyar magánjog, I. kötet [Hungarian private law, Volume I]. Budapest: Grill Károly Könyvkiadó.

Tamás, A. (2011). Közigazgatási jogtudomány [Adminsitrative legal science]. In M. Fazekas (Ed.), A közigazgatás tudományos vizsgálata egykor és ma: 80 éve jött létre a budapesti jogi karon a Magyar Közigazgatástudományi Intézet [The scientific analysis of public administration in the past and today: The Institute of Hungarian Public Administration was established 80 years ago at the law faculty of Budapest] (p. 55-75). Budapest: Gondolat Kiadó.

Van der Hoek, M. P. (2005). Handbook of Public Administration and Policy in the European Union. London: Taylor \& Francis. 


\section{Znanstvena analiza javne uprave Republike Madžarske. Novi trendi in metode.}

Ključne besede: javnoupravna veda na Madžarskem, večdisciplinarnost in multidisciplinarnost, filozofska sinteza, pristop naravnega prava

Javna uprava Republike Madžarske in javnoupravna veda sta že tradicionalno zelo pravnega značaja. Tega ni spremenilo niti dejstvo, da so celo najbolj priznani raziskovalci javnoupravne vede (prej Zoltán Magyary, v bližnji preteklosti pa Lajos Lőrincz) pogosto izražali svoje pomisleke glede enostranske pravne analize javne uprave. Kljub temu je analiza javne uprave, predvsem s pravnimi metodami in s pravnega pristopa, povsem primerna, saj je vprašanja o javni upravi mogoče zakonito homogenizirati, njeni mehanizmi pa zavestno temeljijo na pravu že od začetka 19. stoletja, kar je odločilnega pomena tudi v praksi.

Glede na trenutno prevladujoče večinsko mnenje, analiza notranjih načel upravnega prava najbolje omogoča preučitev katerega koli področja javne uprave. Če namreč primerjamo institucije javne uprave s podobnimi institucijami na drugih področjih prava (na primer upravno odgovornost kot zvrst sistema pravne odgovornosti, z elementi, ki sestavljajo sistem odgovornosti na drugih področjih prava), nam je omogočena širša analiza in s tem tudi nekakšna »notranja pravna multidisciplinarnost«.

Nujnost »notranje pravne multidisciplinarnosti« podpirajo tudi nekatere specifične značilnosti razmerij, ki se urejajo z upravnim pravom. Število in pomembnost tistih kompleksnih pravnih razmerij, ki sovpadajo oziroma se prekrivajo z mejami upravnega in civilnega prava, se povečuje). Slednje se nрг. kaže pri javnih storitvah, ki omogočajo izdajo odločb na podlagi upravnih predpisov iz aktov ali uredb in pri pogodbah civilnega prava, ki te odločbe uresničujejo. Takšne javne storitve in pogodbe civilnega prava namreč sestavljajo enotno in zapleteno (mešano) pravno razmerje, v katerem različni elementi pomembno sovpadajo oziroma se prekrivajo drug z drugim. Ker odločbe in pogodbe prevzemajo druga drugo, je zatorej povezano tudi njihovo uresničevanje. Razumevanje teh zapletenih razmerij je težavna naloga, in sicer tako glede zakonodaje kot tudi glede kazenskega pregona, še zlasti ker je »dogma o tako zapletenih (mešanih) pravnih razmerjih precej manj dodelana», čeprav je treba poudariti, da ne gre za nov pojav.

Poleg zgoraj omenjenih dejavnikov predpostavljamo, da je za preučitev neposrednega predmeta tega dela, tj. javne uprave, potrebna neke vrste interdisciplinarna ali multidisciplinarna metoda, ki bi omogočila oblikovanje verodostojnih nadaljnjih zaključkov in ustanovitev novih analiz. Tako bi bilo 
za predmet preučevanja, poleg metod in rezultatov tradicionalno najmočnejše upravne sodne prakse treba vzpostaviti tudi trden znanstveni in materialni okvir, ki bi bil oblikovan iz znanstvenih metod drugih družboslovnih ved, kot so politične vede, organizacijske vede (organizacijsko-upravne vede), veda o javni politiki, ozko interpretirana veda javne uprave (teorija javne uprave in ekonomije), široko razumljene vede o upravljanju, statistiki, sociologiji, socialni psihologiji ali krščanski socialni etiki ali etiki ekonomije (!), poleg tega pa tudi določenih naravoslovnih ved, pri katerih ali v primerjavi s katerimi ozko interpretirani pravni argumenti in tekstualne preučitve lahko zasedejo svoje pravo mesto in nenazadnje tudi vrednost.

Mednarodna literatura se sklicuje na dejstvo, da so bili v poskusih opisov, ki so jih opravile razne javne uprave, institucionalno osredotočeni pristopi in javna politika dolgo časa v skoraj monopolističnem položaju tudi na mednarodni ravni. Pomembno pa je dejstvo, da razmeroma tradicionalne metode vede o javni upravi, upravni sociologiji in ekonomiji danes dopolnjujejo pristopi teorije mrež, ki so veliko bolj primerni za analiziranje globaliziranega sveta.

Za vzpostavitev dialoga med pravom in drugimi oblikami znanja je potrebno močno interdisciplinarno izhodišče. To danes pomeni večkot le uporabo metod sociologije ali pogovorne analize zaradi pridobitve boljšega razumevanja in pregleda nad pravnimi procesi. Oblikovala se je namreč potreba po usmeritvi k novim znanstvenim področjem, ki prej niso bila oziroma niso v resnici bila povezana z znanostjo o pravu ali ekonomiji (literaturo, antropologiji ali psihologiji in kognitivni nervnoznanosti itd.). Poleg tega dandanes razmerje med njimi ne more biti omejeno na »vzajemno uvedbo« na ravni splošnosti, temveč je potrebna vzpostavitev predhodno oblikovanih interdisciplinarnih postopkov in z njimi povezanih koherentnih in sistematičnih metodam, ki bi bile sposobne zagotoviti trden okvir za materialno primerjalno analizo/raziskavo in bi bile obenem zavezane $k$ fleksibilnosti in odprtosti.

Seveda se ta potreba, ki jo je mogoče zaznati v zgoraj omenjenem multidisciplinarnem pristopu, pri preučevanju upravnega (državnega) pojava ne pojavlja le na strani ozko interpretirane vede o javni upravi in vede o upravnem pravu: multidisciplinarnost potrebuje odcepitev oziroma ločitev od enostranske politične analize institucij in struktur (torej upravnih institucij in struktur): ta preučevanja je treba dopolniti s teoretičnimi in metodološkimi možnostmi, ki jih omogočajo sociološka, ekonomska veda in pravo.

Ta kompleksni pristop na celoto upravnih pojavov utemeljuje dejstvo, da je razlika med procesi sprememb, ki nastajajo v pravu in realnimi družbenimi spremembami, tradicionalno zbledela: potreba po privajanju na novo in pomembnost upravljanja družbe večinoma z zakonodajo se odmika celo v primerih, ko se v resnici ne zgodi prav ničesar.

Zaradi teh lastnosti (značilnosti) je med preučevanjem treba uporabiti metodo oblikovanja modela, seveda, če se javnoupravna veda lahko interpretira kot 
adaptivna kompleksna metoda, pri kateri ločeno preučevanje nekaterih elementov bistveno zmanjša vrednost mogočih razlag. Pri tem modelu se bi odnos države in široko irazumljenih upravnih institucij družbe do drugih organov, trga in mednarodnih integracij itd., zaradi odstopanja zakonodaje od realnosti, preučeval z vseh možnih vidikov, tudi s pristopom oziroma z vprašanjem, ali so upravne reforme posegale v vsebino sistema razmerij in če da, kako in v kolikšni meri.

Kot na drugih področjih, je tudi tu sodobnost povzročila uvajanje novih pojasnjevalnih načel v politični filozofiji. Večina avtorjev, ki je obravnavala dobro upravljanje in red družbenega soobstoja, je dolgo časa razlagala »človeški pojav« na podlagi predpostavk iz ontologije in epistemologije Kartezijansko-Newtonovega etosa, ki je bil v sodobnih naravoslovnih vedah dolgo časa v prevladujočem položaju. Avtorji so zato vsak drugačen pristop šteli za iracionalnega: posameznik je veljal za naravno izhodišče in atomski element družbenih preučevanj. Tako ali drugače so avtorji črpali pravico do obstoja političnih institucij iz dovoljenj, prejetih od posameznikov in/ali naravnih prizadevanj posameznikov, medtem ko so tradicionalna zapuščina in "slepe« sile narave veljale le za ovire, ki jih je bilo treba premagati, da bi bila mogoča nemotena vzpostavitev posameznika. Nevezanost osebnosti in emancipacija sta postala glavna politična (in upravna) cilja in glavno orodje, ki (v prevladujočih pristopih) predstavlja jasno in racionalno moč.

Današnja zakonodaja zahteva, da raziskovalci družbe jasno razlikujejo med dejstvi in izjavami, ki vsebujejo vrednostne sodbe. "Znanstvena večina« za znanstveno vredne in zatorej realne navadno sprejema le prve. Kljub temu je globalna razširjenost racionalnih institucij do konca 20. stoletja privedla do velikih političnih sprememb, in sicer do stopnje, ko so (kompleksno) delovanje mrež, ki poosebljajo »moč znanja«, tehnologija in formalizirani odnosi (na primer, pravo, trg, informacijska tehnologija) postajali vedno bolj neobvladljivi in nujni, poskusi opisa s tradicionalnimi metodami pa nemogoči.

Glede vprašanja »zakaj zakonodaja ne deluje« nismo prejeli še nobenega zadostnega odgovora - tradicionalne oziroma »običajne« metode široko interpretirane vede o ekonomiji in z njo povezana tipična družbeno-znanstvena področja ne dajejo nikakršnih odgovorov. Ni se mogoče izogniti niti ponovni vzpostavitvi filozofske sinteze med pravno normo, ki ureja javno upravo in dejstvi realnega delovanja. Verjetno bo/je lahko ta smer osnova in realizator spremembe paradigme (tudi) v vedah o (javni upravi) na Madžarskem.

Na splošno je mogoče reči, da bo zaradi krize družbenih ved vedno več avtorjev začelo preučevati pravi pomen stvari (širše preučevanje okvirjev analiziranega pojava), namesto opisnih vprašanj, ki analizirajo načine delovanja. V času krize, ko vsakdanje izkušnje ponarejajo naša pričakovanja, pravne in politične vede postajajo vedno bolj radikalne: preučevati in pregledovati morajo veljavnost svojih predpostavk, ki so se prej zdele trdne. Filozofija je zatorej postala ponovno veljavna, saj je vedno težje izključiti vprašanja iz politično-znanstvene 
[in ekonomsko-znanstvene] razprave, ki je obrnjena stran od filozofskega spraševanja, ki se pojavlja z zahtevo opisne vede, ki ni povezana z metodo delovanja, temveč njenim pomenom (okvirom pomena).

Pozornost sodne prakse se usmerja - med drugim - na vprašanje, kako je mogoče, da so moralna načela vedno bolj prisotna v svetu prava ter na področjih, kjer je potreba po slednjih že dolgo ponavljano dejstvo, a kljub temu še vedno ni prišlo do njihove praktične uvedbe, oziroma se je le-ta zgodila le do določene mere (glej na primer vprašanje moralne odgovornosti večinske družbe do romske manjšine v pravnih instrumentih Republike Madžarske). Dokončno znamenje širitve obzorja sodne prakse - interpretiranega v najširšem pomenu besede - je, da bojevniki »tradicionalnega« pravnega pozitivizma kar naprej vzpostavljajo svoje lastne sisteme meril, s pomočjo katerih se ta uvedba lahko dokazano dogaja na vseh mogočih področjih.

Za sodobne ljudi je funkcionalna diferenciacija družbe izkušnja. Vedno bolj očitna avtonomija politike, prava, ekonomije, znanosti in sistemskih delov vere je družbenim vedam pomenila velik izziv, ko bi te pravzaprav morale opisovati ta acentrični - necentrični - svet. Lastnost modernih in "postmodernih« družboslovnih konceptov, ustvarjenih v času brez centralnega vodilnega načela je, da ne (ali ne veliko) upoštevajo filozofsko-moralne narave človeka in se ne dotikajo načel ustreznega družbenega sožitja in z redom povezanih integracijskih družbenih sil ter na ta način tudi opuščajo teoretično oblikovanje izvedljivega družbenega reda oziroma ureditve.

$\checkmark$ zgodnjih civilizacijah sta pravo in religija navadno tvorila enoten kompleks znanja, ki se je sčasoma identificiral kot darilo od Boga, kot močnega organizatorja znanja, (včasih) z dvoumnim oziroma nejasnim poreklom, ki se je ustno prenašal skozi generacije. Eden od glavnih učinkov na sedanje stanje sodobnega prava in sodne prakse izvira iz - predhodne - ločitve z ekskluzivnostjo božanskega naravnega prava: transcendentno (moralno) preverjanje veljavnosti pozitivnega prava, ki ga je izvedel človek v obliki racionalnega naravnega prava. Čeprav potreba po preverjanju veljavnosti pozitivnega prava s transcendentalnimi, t.i. meta-jurističnimi (moralnimi) načeli, še ni izginila, pa se je sama težava preverjanja premaknila v dimenzijo zgodovine neustvarjenega sveta.

Z napredovanjem pozitivizma prava, ločitvijo/razdelitvijo etike in prava (moralnost in legalnost) od krepitve pravnega pozitivizma in potiskanjem pristopa naravnega prava v ozadje, se je za vprašanje »izvora in narave« pravne veljavnosti oblikovala naslednja alternativna rešitev: pozitivno pravo postane veljavno bodisi z odločbo ciljnega racionaliziranega (pravnega!) postopka, ki ne potrebuje nobene transcendentne utemeljitve onkraj prava ali pa obstaja potreba po zunanji utemeljitvi in zanašanju na meta-juristična (moralna) načela. Tokrat naj ugotovimo, da smo dandanes lahko priča počasni krepitvi pristopov naravnega prava, razumljenega v njegovem najširšem pomenu. 
94 International Public Administration Review, Vol. XII, No. 1, 2014 